\title{
Calorimetric Computation of Enthalpy of Formation of Trisacetylacetonato Chromium(III) $\left[\mathrm{Cr}\left(\mathrm{C}_{5} \mathrm{H}_{7} \mathbf{O}_{2}\right)_{3}(\mathrm{c})\right]$
}

\author{
Madhvendu Pathak ${ }^{1}$ and Raghvendu Pathak ${ }^{2 *}$ \\ ${ }^{1}$ Department of Chemistry, Lunglei Government College, Lunglei-796701, Mizoram, India \\ ${ }^{2}$ Department of Chemistry, Pachhunga University College, Aizawl-796001, Mizoram, India \\ E-mail: *rppuc41@yahoo.com
}

\begin{abstract}
From thermochemical studies of organometallic compounds, a host of thermodynamic parameters viz., heat capacity, entropy, Gibbs energy etc., can be evaluated. The present communication deals with the evaluation of enthalpy of combustion and thereby estimation of enthalpy of formation of crystalline trisacetylacetonato chromium(III) $\left.\left[\mathrm{Cr}\left(\mathrm{C}_{5} \mathrm{H}_{7} \mathrm{O}_{2}\right)_{3} \text { (c)] or [Cr (acac) }\right)_{3}(\mathrm{c})\right]$ bomb-calorimetrically. The enthalpy of combustion $\left(\Delta_{c} \mathrm{H}\right)$ and enthalpy of formation $\left(\Delta_{\mathrm{f}} \mathrm{H}^{\circ}\right)$ values have been evaluated to be $-7997 \cdot 16 \pm 10 \mathrm{k} \mathrm{J} \mathrm{mol}^{-1}$ and $-1470 \cdot 315 \pm 15 \mathrm{~kJ} \mathrm{~mol}^{-1}$ respectively. Experimental data obtained are in good agreement with one another.
\end{abstract}

Keywords: Calorimetric Computation, Organometallic Compounds, Combustion Enthalpy, Trisacetylacetonato Chromium (III)

\section{INTRODUCTION}

Thermochemical studies of organometallic compounds of $\mathrm{s}, \mathrm{p}, \mathrm{d}$ and $\mathrm{f}$ block elements have evoked a lot of interest among the researchers of various fields since long as they provide a lot of physico-chemical data for scientists to deal with (Cavell et al., 1977, Lalancette et al., 2018, Ismail 1991, Semyannikov et al., 2005, Pathak 2016, da Silva et al., 2011, Thakur et al., 1995, da Silva et al., 1988, Thakur et al., 1992, Melia et al., 1968) which can be applied in various fields ranging from material chemistry to energetic and from environmental chemistry to biochemistry. Available literature also buttresses such facts. Quantitative measurements of enthalpy changes involving various physico-chemical and biological processes are tedious tasks and usually done through the help of various types of calorimeters (Ribeiro da Silva 2010) or otherwise. The data so obtained as a consequence of such thermochemical investigations by several investigators are, therefore, of much empirical importance. The present paper deals with the bomb-calorimetric evaluation of enthalpy of combustion and thereby estimation of enthalpy of formation of trisacety lacetonatochromium(III) $\left[\mathrm{Cr}\left(\mathrm{C}_{5} \mathrm{H}_{7} \mathrm{O}_{2}\right)_{3}\right.$ (c)].

\section{EXPERIMENTAL}

Preparation of trisacetylacetonato chromium(III) $\left[\mathrm{Cr}\left(\mathrm{C}_{5} \mathrm{H}_{7} \mathrm{O}_{2}\right)_{3}(\mathrm{c})\right]$ :

Trisacetylacetonato chromium(III) was prepared by adding $5 \mathrm{~g}$ of chromium(III) oxide $\left[\mathrm{CrO}_{3}\right.$ (s), Merck grade] gradually in very small amounts to about $25 \mathrm{~g}$ of acetyacetone (b.p. $137-140^{\circ} \mathrm{C}$ ) with constant stirring until the exothermicity of the reaction subsided and the solution turned violet. Stirring continued for another 10 minutes when $5 \mathrm{ml}$ of $\mathrm{C}_{2} \mathrm{H}_{5} \mathrm{OH}$ was added. The solution was heated over a steam bath for about 4 hours and then allowed to cool in a freezer for about an hour when dark pink solids separated out. After aqueous-washing of the precipitate (ppt) several times, it was recrystallised in minimum volume of benzene with the addition of small amount of light petroleum (b.p. $40-60^{\circ} \mathrm{C}$ ). It was then cooled in a freezer for an hour whereby shining pink crystals of the compound separated out. It was then filtered and dried in vacuum (m.p. $215^{\circ} \mathrm{C}$ ). The said compound was analysed for chromium. (Found: $\mathrm{Cr}=15 \%$; calculated for $\mathrm{Cr}\left(\mathrm{C}_{5} \mathrm{H}_{7} \mathrm{O}_{2}\right)_{3}$; 14.9\%. It may be sublimed without any residue. However, preparation of the said compound as reported by few other 
investigators is also given here (Fernelius et al., 1957, Chaudhuri, et al., 1982). The compound is usually prepared by the action of acetylacetone (Hacac) on Chromium (III) oxide (Fernelius et al., 1957)

$$
\mathrm{Cr}_{2} \mathrm{O}_{3}+6 \mathrm{Hacac} \rightarrow 2 \mathrm{Cr}(\mathrm{acac})_{3}+3 \mathrm{H}_{2} \mathrm{O}
$$

Derived from gum benzoin and used as food preservatives, benzoic acid is a colourless crystalline solid occurring naturally in many plants (Qualley et al., 2012 ) and fruits including berries $(\sim 0.05 \%)$ and serves as an intermediate in the biosynthesis of many secondary metabolites. Benzoic acid usually contains phthalic acid and benzylbenzoate as impurities, hence for calibration of the bomb calorimeter extra pure benzoic acid usually called certified grade pure benzoic acid is utilized. It is usually a stable compound and relatively non-toxic.

'Toshniwal' static oxygen bomb calorimeter having capacity of $303 \mathrm{ml}$ and which can withstand a pressure of $200 \mathrm{~atm}$. was used in the present work. The mean heat capacity of the bomb calorimeter was determined by burning a certified grade pure benzoic acid and it was found to be $10550 \pm 10 \mathrm{~J}^{\circ} \mathrm{C}^{-1} \mathrm{~g}^{-1}$.

The problems of not using differential scanning calorimetry (DSC) in the present work were manifold. First of all the reference sample should have a well-defined heat capacity over the range of temperatures to be scanned and secondly either the power supply remains constant throughout or the heat flux remains constant throughout during scanning of the sample, which are difficult to control. Moreover, due to a combination of relatively poor sensitivity, slower than normal scan rates (typically $2-3^{\circ} \mathrm{C} / \mathrm{min}$, due to much heavier crucible) and unknown activation energy, it makes imperative to deduct about $75-100^{\circ} \mathrm{C}$ from the initial start of the observed exotherm to suggest a maximal temperature for the material (Wikipedia). Moreover, DSC curves reveal considerably less energy release than the true reaction-heats of the oxidation of organic materials which may be due to the low oxidation rate of some primary volatile products, especially carbon monoxide, inevitably forming during the oxidation of organic and carbonaceous materials at the temperatures of DSC experiments (Várhegyi et al., 1986).

\section{RESULTS AND DISCUSSION}

Recording temperature rise by burning a weighed amount of the sample in a specified amount of water in presence of excess of $\mathrm{O}_{2}(\mathrm{~g})$ under pressure, the enthalpy of combustion $\left(\Delta_{c} \mathrm{H}\right)$ of the compound was evaluated using the relation

$$
\Delta_{\mathrm{c}} \mathrm{H}=\mathrm{MW} \Delta \mathrm{t}
$$

where, $\mathrm{M}$ is the formula weight of the crystalline complex, $\mathrm{W}$ the water equivalent of the bomb calorimeter and $\Delta t$, the temperature rise per gram of the sample due to calorimetric combustion. Mean water equivalent of the bomb calorimeter was obtained experimentally by burning certified grade benzoic acid and was found to be $10550 \pm 10 \mathrm{~J}^{\circ} \mathrm{C}^{-1} \mathrm{~g}^{-1}$. The molar enthalpy of combustion of the sample was given in table 1 .

By substituting the supplementary thermochemical data from the standard reference sources (Wagman et al., 1965, Weast 1986), the standard enthalpies of formation of [ $\mathrm{Cr}\left(\mathrm{C}_{5} \mathrm{H}_{7} \mathrm{O}_{2}\right)_{3}$ (c)] was computed using the relation $\Delta_{\mathrm{c}} \mathrm{H}=\Sigma \Delta_{\mathrm{f}} \mathrm{H}^{\mathrm{o}}$ (products) $-\Sigma \Delta_{\mathrm{f}} \mathrm{H}^{\circ}$ (reactants). The auxiliary enthalpy of formation data for products like metal oxides, $\mathrm{CO}_{2}(\mathrm{~g})$ and $\mathrm{H}_{2} \mathrm{O}(\mathrm{l})$ have also been taken from standard reference sources (Codata 1978, Weast 1978 Lange's Handbook of Chemistry. (1973).

Table 1: Molar Enthalpy of Combustion $\left(\Delta_{c} H\right)$ of $\left[\mathrm{Cr}\left(\mathrm{C}_{5} \mathrm{H}_{7} \mathrm{O}_{2}\right)_{3}(\mathrm{c})\right]$

$\left(\right.$ Molar mass $\left.=349 \cdot 32 \mathrm{~g} \mathrm{~mol}^{-1}\right)$

\begin{tabular}{|l|l|l|l|}
\hline \multicolumn{1}{|c|}{ Experiment No. } & $\mathbf{1}$ & $\mathbf{2}$ & $\mathbf{3}$ \\
\hline Wt. of the sample $(\mathrm{g})$ & 0.3385 & 0.5435 & 0.6324 \\
\hline Temperature rise $\left({ }^{\circ} \mathrm{C}\right)$ & 0.737 & 1.179 & 1.368 \\
\hline $\begin{array}{l}\text { Temp. rise per g of the } \\
\text { sample } \Delta \mathrm{t}\left({ }^{\circ} \mathrm{C}\right)\end{array}$ & 2.180 & 2.169 & 2.163 \\
\hline
\end{tabular}

Mean temperature rise per gm of the sample, $\Delta t=2 \cdot 170$

Now,

$$
\begin{aligned}
-\Delta_{\mathrm{c}} \mathrm{H} & =\mathrm{M} \times \mathrm{W} \times \Delta \mathrm{t} \\
& =349.32 \times 10550 \times 2.170 \\
& =7997157.42 \mathrm{~J} \mathrm{~mol}^{-1} \\
& =7997.16 \mathrm{~kJ} \mathrm{~mol}^{-1}
\end{aligned}
$$

Therefore, $\Delta_{c} \mathrm{H} \quad=-7997 \cdot 16 \pm 10 \mathrm{k} \mathrm{J} \mathrm{mol}^{-1}$

where, $\mathrm{M}=$ molar mass of the sample, $\mathrm{W}=$ water equivalent of the bomb calorimeter $=10550 \mathrm{~J}^{\circ} \mathrm{C}^{-1} \mathrm{~g}^{-1}$, and $\Delta \mathrm{t}$ $=$ mean temperature rise per gm combustion of the sample $=2.170^{\circ} \mathrm{C}$.

Computation of standard enthalpy of formation $\left(\Delta_{\mathrm{f}} \mathrm{H}^{\circ}\right)$ of $\left[\mathrm{Cr}\left(\mathrm{C}_{5} \mathrm{H}_{7} \mathrm{O}_{2}\right)_{3}\right.$ (c)]: 
By substituting supplementary data from literatures [17-18], standard enthalpy of formation of trisacetylaceton atochromium(III) $\left[\mathrm{Cr}\left(\mathrm{C}_{5} \mathrm{H}_{7} \mathrm{O}_{2}\right)_{3}\right.$ (c)] was computed.

$$
\begin{aligned}
& \mathrm{Cr}\left(\mathrm{C}_{5} \mathrm{H}_{7} \mathrm{O}_{2}\right)_{3}(\mathrm{c})+\mathrm{O}_{2} \text { (g) (excess) }=1 / 2 \mathrm{Cr}_{2} \mathrm{O}_{3}(\mathrm{c})+15 \mathrm{CO}_{2} \\
& (\mathrm{~g})+10 \cdot 5 \mathrm{H}_{2} \mathrm{O} \text { (l) } \Delta \mathrm{H}=\Delta_{\mathrm{c}} \mathrm{H} \\
& \Delta_{\mathrm{c}} \mathrm{H}=\Sigma \Delta_{\mathrm{f}} \mathrm{H}^{\circ} \text { (products) }-\Sigma \Delta_{\mathrm{f}} \mathrm{H}^{\circ} \text { (reactants) } \\
& \Delta_{\mathrm{c}} \mathrm{H}=1 / 2 \Delta_{\mathrm{f}} \mathrm{H}^{\circ} \mathrm{Cr}_{2} \mathrm{O}_{3} \text { (c) }+15 \Delta_{\mathrm{f}} \mathrm{H}^{\circ} \mathrm{CO}_{2}(\mathrm{~g})+10 \cdot 5 \Delta_{\mathrm{f}} \mathrm{H}^{\circ} 10 \mathrm{H}_{2} \mathrm{O} \\
& \text { (l) }-\Delta_{\mathrm{f}} \mathrm{H}^{\circ} \mathrm{Cr}_{5}\left(\mathrm{C}_{5} \mathrm{H}_{7} \mathrm{O}_{2}\right)_{3}(\mathrm{c})
\end{aligned}
$$

Therefore,

$$
\begin{aligned}
\Delta_{\mathrm{f}} \mathrm{H}^{\circ} \mathrm{Cr}\left(\mathrm{C}_{5} \mathrm{H}_{7} \mathrm{O}_{2}\right)_{3}(\mathrm{c}) & =1 / 2 \Delta_{\mathrm{f}} \mathrm{H}^{\circ} \mathrm{Cr}_{2} \mathrm{O}_{3}(\mathrm{c})+15 \Delta_{\mathrm{f}} \mathrm{H}^{\circ} \mathrm{CO}_{2}(\mathrm{~g}) \\
& +10.5 \Delta_{\mathrm{f}} \mathrm{H}^{\circ} 10 \mathrm{H}_{2} \mathrm{O}(\mathrm{l})-\Delta_{\mathrm{c}} \mathrm{H} \\
& =1 / 2 \times(-1128 \cdot 15+15 \times(-393 \cdot 5) \\
& +10.5 \times(-285 \cdot 8) \\
& -(-7997 \cdot 16) \\
& =-564 \cdot 075-5902 \cdot 5 \quad-3000 \cdot 9 \\
& +7997 \cdot 16 \\
& =-9467 \cdot 475+7997 \cdot 16 \\
& =-1470.315 \pm 15 \mathrm{kJmol}^{-1} .
\end{aligned}
$$

The present value of $-1470 \cdot 315 \pm 15 \mathrm{kJmol}^{-1}$ was compared with those obtained by Hill and Irving $\left\{\Delta H_{\mathrm{f}}^{\circ}=-366 \cdot 48 \pm 0.67 \mathrm{kcal} / \mathrm{mole}\right\}$ (Hill et al.,1967) and Silva and Ferrao, $\left\{-1564 \cdot 8 \pm 8.9 \mathrm{kJmol}^{-1}\right\}$ (da Silva at el., 1988). However, Melia and Merrifield (Melia at el., 1968) have calculated the standard heat of formation and entropy of gaseous tris (acetylacetonato) chromium (III) at $298 \cdot 16^{\circ} \mathrm{K}$ and 1 atmosphere pressure to be $\Delta H_{\mathrm{f}}^{\circ}=-344 \cdot 7 \pm 1.0 \mathrm{k} \mathrm{cal} \mathrm{mole}^{-1}$ and $S_{298 \cdot 16}^{\circ}-S_{0}^{\circ}=142 \cdot 4 \pm 1 \cdot 0 \mathrm{cal} \mathrm{deg}^{-1} \mathrm{~mole}^{-1}$ respectively.

\section{CONCLUSION}

Oxygen consumption calorimetry is used to measure the heat of combustion of the pyrolysis products and the maximum amount of heat released per unit mass per degree of temperature $\left(\mathrm{Jg}^{-1} \mathrm{~K}^{-1}\right)$ is a material property that appears to be a good indicator of flammability or efficiency of the process (Lyon et al., 2004). As we all know, chemical, physical and biological changes are often accompanied by energy transfer. The high negative value of $\Delta_{\mathrm{f}} \mathrm{H}^{\circ}$ of $\left[\mathrm{Cr}\left(\mathrm{C}_{5} \mathrm{H}_{7} \mathrm{O}_{2}\right)_{3}(\mathrm{c})\right]$ indicates the exothermicity of the reaction and stability of the compound. The enthalpy of formation a compound can be correlated to the efficiency of a heat engine. The higher the negative value of standard enthalpy of formation of a compound, the more heat will be given off, and therefore the more fuel-efficient the compound would be.

\section{REFERENCES}

Cavell KJ, Pilcher G (1977) Enthalpies of combustion of tris(acetylacetonato) derivatives of aluminium(III), gallium(III) and indium(III). J. Chem. Soc., Faraday Trans. 1. 73: 1590-1594.

Chaudhuri MK, Roy N, Khathing DT (1982) Synthesis of Tris (Acetylacetonato) Cheomium (III), $\mathrm{Cr}\left(\mathrm{C}_{5} \mathrm{H}_{7} \mathrm{O}_{2}\right)_{3}$. J. Synth. React. Inorg. Metal-Org. Chem., 12: 715-720.

Codata (1978) The International Council of Scientific Union (ICSU) Committee on Data for Science and Technology. 10: 903-1010.

Fernelius WC, Blanch JE, Bryant, BE, Terada K, Drago RS, Stille JK (1957) Chromium(III) Acetylacetonate. In: Inorganic Syntheses (ed) Therald Moeller, McGraw-Hill Book Company, Inc. NY, 5: 130-131.

Hill JO, Irving RJ (1967) Standard heat of formation of tris (acetylacetonato) chromium(III) at $25^{\circ}$ and the metal-oxygen bond energy. J. Chem. Soc. A. 1413-1416.

Ismail HM (1991) A thermoanalytic study of metal acetylacetonates. J. Analy. Appl. Pyrol. 21: 315-326.

Lalancette R, Syzdek D, Grebowicz J, Arslan E (2018) The thermal decomposition and analyses of metal tris-acetylacetonates: Free radical formation from $\mathrm{Al}, \mathrm{Cr}, \mathrm{Mn}, \mathrm{Fe}$ and Co complexes. J. Therm. Analy. Calorim. 135 3463-3470.

Lange's Handbook of Chemistry (1973) Dean, JA, (ed), $11^{\text {th }}$ Edition, McGraw Hill Book, NY., 1600.

Lyon RE, Walters RN (2004) Pyrolysis combustion flow calorimetry. J. Analy. Appl. Pyrol. 71: 27-46.

Melia TP, Merrifield R (1968) Thermal properties of transitionmetal compounds. Part I. Heat capacity, entropy, and standard heat of formation of tris(acetylacetonato)chromium(III). J. Chem. Soc. A. 2819-2820.

Pathak R (2016) Thermochemical studies of thorium(IV) and zirconium(IV) tetrabenzoates. Sci. Vis. 16: 10-15.

Qualley AV, Widhalm JR, Adebesin F, Kish CM Dudareva N (2012) Completion of the core $\beta$-oxidative pathway of benzoic acid biosynthesis in plants, Proceedings of the National Academy of Sciences, 109: 16383-16388.

Retrieved January 3, 2020, from https:// en. wikipedia. org/ wiki/ Differential scanning calorimetry

Ribeiro da Silva MAV, Ferrao MLCCH (2011) Standard enthalpies of formation of tris( $\beta$-diketonate) manganese(III) complexes: the mean (Mn-0) bond-dissociation enthalpies. Canad. J. Chem. 66: 651-654.

Ribeiro da Silva MAV, Ferrao MLCCH (1988) Energetics of metaloxygen bonds in metal complexes of $\beta$-diketones. Pure \& Appl. Chem. 60: 1225-1234.

Ribeiro da Silva MAV (2010) The development of calorimetry and thermochemistry in Portugal. J. Therm. Anal. Calorim. 100: 373-374. 


\section{Calorimetric Computation of Enthalpy of Formation}

Semyannikov PP, Igumenov IK, Trubin SV, Chusova TP, Semenova ZI (2005) Thermodynamics of chromium acetylacetonate sublimation. Thermochim. Acta 432: 91-98.

Thakur S, Kumar A, Pathak R. (1995) Standard Heats of Formation of Uranyl (II) and Thorium (IV) Oxinates. J. Indian Chem. Soc. 72: 823-24.

Thakur L, Thakur S, Pathak M, Jha RN (1992) Thermochemical Studies of diaquodipropionatodioxouranium (VI). J. Indian Council of Chemists. VIII: 25-26.
Várhegyi G, Szabó P, Till F (1986) Problems in the DSC and DTA study of the burning properties of fuels and other organic materials, Thermochim. Acta, 106:191-199.

Wagman DD, Evans WH, Halow I, Parker VB, Baitey SM, Schumm RH, Churney KL (1965).'Selected Values of Chemical Thermodynamic Properties', NBS, Technical Notes, Washington D.C., 1-132.

Weast RC (1986) Handbook of Chemistry and Physics, $61^{\text {st }}$ Edition, CRC Press, Florida

Weast RC (1978) Handbook of Chemistry and Physics, $59^{\text {th }}$ Edition, CRC Press, Florida, 1- 2488. 